\title{
STRATEGI PEMERINTAH DESA DALAM MENGEMBANGKAN OBJEK WISATA PANTAI MELEURA DI DESA LAKARINTA KECAMATAN LOHIA KABUPATEN MUNA
}

\author{
Resti $^{1}$ \\ ${ }^{1}$ Alumni Pendidikan Geografi FKIP UHO
}

\begin{abstract}
Abstrak: Tujuan dalam penelitian ini adalah untuk mengetahui strategi yang dilakukan Pemerintah desa dalam mengembangkan objek wisata pantai meleura di Desa Lakarinta, Kecamatan Lohia Kabupaten Muna, dengan menggunakan metode perumusan strategi analisis SWOT. Data dikumpulkan melalui observasi, wawancara, serta dokumentasi. Berdasarkan hasil penelitian ini maka dapat disimpulkan strategi yang bisa dilakukan pemerintah desa dalam mengembangkan objek wisata pantai meleura antara lain: Meningkatkan promosi objek wisata, Meningkatkan sarana dan prasarana serta infrastruktur yang menunjang seperti pembuatan taman wisata, pembuatan air terjun, perluasan parkir, penataan parkir, pelebaran jalan, penyediaan kuliner khas muna, penyediaan wahana permainan air seperti banana boat, aquarium dibawah laut, dan fasilitas-fasilitas penunjang lainnya sehingga menarik dan memberi kenyamanan bagi pengunjung serta mengadakan akomodasi pariwisata baik itu hotel, maupun villa, serta mengembangkan atraksi wisata dan melakukan koordinasi dengan pihak swasta untuk menanamkan modal agar pengembangan pantai meleura cepat terlaksana.
\end{abstract}

Kata kunci: Strategi, Pemerintah Desa, Pengembangan, Pantai Meleura 


\title{
STRATEGY OF VILLAGE GOVERNMENT IN DEVELOPING OBJECT OF COASTAL TOURISM MELEURA IN LAKARINTA VILLAGE DISTRICT LOHIA MUNA REGENCY
}

\author{
Resti $^{1}$ \\ ${ }^{1}$ Alumni of Geography Education of Halu Oleo University
}

\begin{abstract}
The objectives of this research aredetermine the strategies undertaken by the village government in developing coastal tourist attraction meleura in Lakarinta Village District Lohia Muna Regency, using the method of SWOT analysis strategy formulation. Data were collected through observation, interviews and documentation. Based on the result of this research, it can be concluded that strategy can be done by village government in developing coastal tourism object of meleura, among others: Improving tourism promotion, improving facilities and infrastructure as well as supporting infrastructure such as making tourism park, waterfall development, parking expansion, parking arrangement, widening the road, providing typical muna culinary, providing games such as banana boats, underwater aquariums, and other supporting facilities so as to attract and provide comfort for visitors, make tourism accommodation be it hotel or villa, develop tourist attractions and coordinate with the private sector to invest capital for the development of coastal meleura quickly implemented.
\end{abstract}

\section{Keywords: Strategy, Village Government, Development, Meleura Beach}

\section{PENDAHULUAN}

Pariwisata merupakan bagian yang tidak terpisahkan dari kehidupan manusia terutama dalam kegiatan sosial dan ekonomi, dalam menghadapi tantangan dan peluang telah dilakukan perubahan peran pemerintah dibidang kebudayaan dan pariwisata yang pada masa lalu berperan sebagai pelaksana pembangunan, saat ini lebih difokuskan hanya kepada tugas-tugas pemerintahan terutama sebagai fasilitator agar kegiatan pariwisata yang dilakukan dapat berkembang dengan pesat. Pengembangan pariwisata pada dasarnya merupakan suatu aktivitas untuk segala potensi pariwisata yang berasal dari sumber daya alam, manusia, ataupun buatan yang semuanya saling berpengaruh satu dengan yang lainnya (Happy Marpaung, 2002).Tujuan utama dalam mengembangkan pariwisata yang melibatkan peran masyarakat secara aktif adalah untuk memberdayakan masyarakat, memperbaiki ekonomi masyarakat dan meningkatkan pendapatan daerah setempat, karena secara teoritis semakin berperan aktif masyarakat dalam aktivitas pariwisata maka kesempatan kerja masyarakat juga semakin terbuka sehingga pendapatan masyarakat semakin meningkat.

Memiliki objek wisata disuatu daerah merupakan keunggulan tersendiri bagi suatu daerah. Tentunya objek wisata tersebut memiliki keunikan tersendiri yangmembedakannya dengan daerah lain. Pasalnya, keberadaan objek wisata tersebut dapat meningkatkan pendapatan ekonomi masyarakat, serta meningkatkan penerimaan pemerintah melalui pajak dan retribusi.Tak heran bila pemerintah, baik skala nasional maupun lokal, berlombalomba memperkenalkan objek wisata kepada para wisatawan, baik asing maupun domestik.Sebab, makin banyak kunjungan wisatawan ke wilayah tersebut, maka makin besar pula manfaat yang diperoleh.

Pantai Meleura merupakan objek wisata pantai yang terletak di Desa Lakarinta Kecamatan Lohia Kabupaten Muna yang memiliki daya tarik untuk dikembangkan sebagai daerah tujuan wisata baik untuk pasar wisata Nusantara maupun Mancanegara.Pantai Meleura merupakan salah satu sektor pantai yang yang strategis dan potensial untuk dikembangkan dan 
dipasarkan.Objek wisata pantai meleura merupakan objek wisata yang mempunyai daya tarik tinggi dengan suasana dan pemandangan alam yang sangat memukau dan sangat indah. Objek wisata yang terdapat di Desa Lakarinta ini mempunyai potensi sebagai objek wisata yang didukung oleh keberadaannya sebagai suatu kawasan yang memiliki potensi sangat besar yaitu pesona alam pantai yang sangat indah, hamparan laut biru, dikelilingi batuan cadas dan ditengah-tengah hamparan laut biru itu terdapat pulau-pulau karang kecil. Pasir putih pun terdapat di pantai meleura, hanya saja adanya didasar laut, yang terlihat dari atas permukaan laut karena begitu jernihnya air laut.

Dari uraiandiatasperludisadari olehseluruh stakeholder pengembangan objek wisata (pemerintah, pengusaha dari bidang pariwisata maupun masyarakat). PemerintahDesa dan Pemerintah Daerah dalamhal ini Dinas Kebudayaan dan Pariwisatayangsangatberperan penting dalam mengembangkansuatu objekwisata mengingatbahwaobjekwisatapantai

meleuraadalahsalahsatu

tempatwisatayangmempunyai potensi yangsangat besardalam menumbuhkanpendapatandaerah.Solusi-

solusi yangdimaksud

dalamhaliniadalahstrategi

terkaitdenganpengembanganobjekwisatapant ai meleuraagar dapat lebih berdaya saing dalam menarik wisatawan.

$$
\text { Strategi sebagai }
$$

bentukupayayangdilakukanuntuk

menciptakandan melestarikan

kawasanwisatadengan

menciptakanstrategiyangsesuaidenganpenge

mbangan kawasanobjek wisatapantai

meleura

ini.SehinggadengandemikianPemerintah

DesaMaupun elemen-elemen yang memiliki tanggung dalam dalam pengembangan objek wisata ini dapat mengambillangkahyangstrategisdari

pilihanyangada.

Strategi menjadisangatpentingbagipengembanganobj ek wisata pantai meleurabaiktujuan jangka pendekmaupun jangkapanjang. Oleh karenaitu, penyusunan strategi merupakan langkah taktis yang bersifat sistematis dalam pencapaian tujuan organisasi. Dengan demikian jika hal-hal ini terus mendapat perhatian serius potensi pantai meleura ini akan mendatangkan manfaat yang optimal terutama untuk untuk meningkatkan kunjungan wisatawan.

Atas dasar itulah peneliti melakukan penelitian tentang : " Strategi Pemerintah Desa Dalam Mengembangkan Objek Wisata Pantai Meleura di Desa Lakarinta Kecamatan Lohia Kabupaten Muna".

Strategi adalah suatu seni menggunakan kecakapan dan sumber daya suatu organisasi untuk mencapai sasarannya melalui hubunganya yang efektif dengan lingkungan dalam kondisi yang paling menguntungakan. (J.Salusu, 1998).Menurut Craig \& Grant (1996) strategi adalah penetapan sasaran dan tujuan jangka panjang (targeting and long-term goals) sebuah perusahaan dan arah tindakan serta alokasi sumber daya yang diperlukan untuk mencapai sasaran dan tujuan (achieve the goals and objectives).

Perumusan strategi antara lain dapat didasarkan atas analisis SWOT. Menurut Udaya, dkk (2013: 40) Analisis SWOT adalah analisis kekuatan (strength), kelemahan(weakness), peluang (opportunities), ancaman (threaths) yang dihadapi perusahaan atau organisasi.Kekuatan merupakan hal atau kondisi yang dapat mendorong atau menumbuhkan suatu kegiatan, usaha atau produksi.Kelemahan merupakan keterbatasan atau kekurangan dalam salah satu sumber daya atau kemampuan (capability) organisasi dibandingkan dengan para pesaingnya yang menciptakan kerugian dalam usaha memenuhi kebutuhan para pelanggan secara efektif.Peluang yaitu kemampuan yang dimiliki oleh suatu daerah untuk dapat dimanfaatkan dan berkembang dimasa yang akan datang. Peluang ini bertujuan untuk memajukan objek wisata. Ancaman merupakan situasi utama yang tidak menyenangkan didalam sebuah lingkungan.

Pemerintahan Desa merupakan bagian dari Pemerintahan Nasional yang penyelenggaraannya ditujukan pada 
pedesaan. Pemerintah Desa adalah suatu proses dimana usaha-usaha masyarakat desa yang bersangkutan dipadukan dengan usahausaha pemerintah untuk meningkatkan taraf hidup masyrakat (Maria Eni Surasih, 2003: 23).

MenurutPitana

(2005:56),pengembanganpariwisataadalahke giatan untukmemajukan suatutempatatau daerahyangdianggapperlu ditata sedemikianrupa

baikdengancaramemeliharayang

sudahberkembang ataumenciptakanyang baru.

\section{METODE PENELITIAN}

\section{Jenis Penelitian}

Dalam penelitian ini, peneliti menggunakan tipe penelitian deskriptif dengan pendekatan kualitatif. Menurut Moleong (2007:6) mendefinisikan Penelitian kualitatif adalah penelitian yang bermaksud untuk memahami fenomena tentang apa yang dialami oleh subyek penelitian secara holistik dan dengan cara deskripsi dalam bentuk kata-kata dan bahasa, pada suatu konteks khusus yang alamiah dan dengan memanfaatkan berbagai metode ilmiah. Dengan menggunakan tipe kualitatif dimaksudkan untuk memahami dan mengetahui kekuatan, kelemahan, peluang serta ancaman dari objek wisata pantai meleura dan bagaimana strategi pengembangan objek wisata pantai meleura.

\section{Tempat dan Waktu Penelitian}

Tempat penelitian ini terletak di kawasan objek wisata pantai meleura Desa Lakarinta, Kecamatan Lohia Kabupaten Muna. Penelitian akan dilaksanakan pada bulan April sampai dengan bulan Mei tahun 2018.

\section{Subjek dan Objek Penelitian}

\section{Subjek Penelitian}

Subjek penelitian adalah sumber tempat memperoleh keterangan atau informan. Untuk mendapatkan informan maka peneliti menggunakan teknik purposive sampling. Teknik Purposive Sampling (pengambilan sampel berdasarkan tujuan) yakni pengambilan sampel berdasarkan kapasitas dan kapabelitas atau yang kompeten/benar-benar dibidangnya.Penentuan sumber/ subjek penelitian ini berdasarkan atas informasi apa saja yang dibutuhkan. Adapun informan yang dibutuhkan pada penelitian kali ini untuk menggali data yaitu :
a. Dinas Pariwisata Kabupaten Muna
b. Kepala Desa
c. Pengelola wisata
d. Pengunjung
e. Tokoh masyarakat

\section{Objek Penelitian}

Dalam penelitian ini yang menjadi objek dari penelitian adalah:

1. Menganalisis faktor Kekuatan, Kelemahan,Peluang dan Ancaman dalam pengembangan Objek Wisata Pantai Meleura.

2. Strategi Pengembangan yang akan dilakukan oleh Pemerintah desa

\section{Teknik Pengumpulan Data}

Dalam penelitian ini, teknik pengumpulan data yang digunakan adalah:

a. Observasi

Observasi menurut Creswell adalah proses untuk memperoleh data dari tangan pertama dengan mengamati orang dan tempat pada saat dilakukan penelitian. Peneliti melakukan pengamatan secara langsung terhadap objek wisata pantai meleura .

b. Wawancara

Wawancara adalah pertemuan dua orang untuk bertukar informasi dan ide melalui tanya jawab, sehingga dapat dikonstruksikan makna dalam suatu topik tertentu.Dalam penelitian ini, peneliti melakukan wawancara mendalam terhadap beberapa informan atau narasumber untuk mendapatkan data yang berkaitan dengan topik penelitian. 
c. Dokumentasi

Dokumentasi adalah proses memperoleh informasi data melalui dokumen dokumen tertulis seperti arsip surat, data statistik, dan laporan-laporan maupun catatancatatan lainya. Dalam penelitian ini dokumentasi yang digunakan oleh peneliti adalah berupa dokumen tentang foto-foto kegiatan tentang potensi objek wisata pantai meleura, rekaman suara dari para informan dan data-data statistik. Data ini dimaksudkan untuk melengkapi data yang tidak diperoleh dari metode wawancara maupun observasi.

\section{Teknik Analisis Data}

Dalam penelitian ini teknik yang digunakan untuk menganalisis adalah teknik analisis deskriptif untuk menjawab faktor kekuatan, kelemahan, peluang dan ancaman.Sedangkan untuk menjawab strategi pengembangan objek wisata pantai meleura menggunakan analisis SWOT. Analisis ini dilandasi dengan keyakinan terhadap asumsi bahwa strategi efektif akan mampu memaksimalkan kelemahan dan menimalisir berbagai ancaman. Dalam penelitian ini tehnik analisis yang digunakan adalah teknik analisis SWOT, yang meliputi

a. Strategi SO (Strength Opportunity Strategy), yaitu analisis strategi yang dibuat dengan memanfaatkan seluruh kekuatan untuk mendapatkan dan memanfaatkan peluang yang ada dilingkungan eksternal dengan sebesar-besarnya.

b. Strategi WO (Weakness Opportunity), yaitu analisis strategi yang diterapkan untuk memperbaiki kelemahan lingkungan internal dengan memanfaatkan peluang yang ada dari lingkungan eksternal.

c. Strategi ST (Strength Threat), yaitu analisis dalam menggunakan kekuatan yang dimiliki untuk menghindari atau mengatasi ancaman yang datang dari lingkungan eksternal d. Strategi WT (Weakness Threat), yaitu analisis strategi yang didasarkan pada kegiatan yang berusaha meminimalkan kelemahan yang ada serta menghindari ancaman.

\section{Instrumen Penelitian}

Instrumen penelitian merupakan suatu alat bantu yang digunakan dalam melakukan penelitian. Adapun alat yang digunakan berupa pedoman wawancara, kamera dan alat perekam. Tujuan dari adanya instrumen penelitian dengan alat bantu ini yaitu untuk memberi kemudahan kepada peneliti dalam melakukan penelitian. Instrument penelitian ini di gunakan sebagai acuan dalam pengumpulan data yang di lakukan dengan memberikan pertanyaan kepada informan.

\section{GAMBARAN UMUM LOKASI PENELITIAN}

\section{A. Gambaran Umum Lokasi Penelitian}

Lokasi Objek Wisata Pantai Meleura terletak di Desa Lakarinta Kecamatan Lohia Kabupaten Muna. Kabupaten Muna merupakan salah satu Kabupaten di Sulawesi Tenggara, bahasa yang dipakai penduduk pribumi juga menggunakan bahasa Muna. Daerah ini dahulunya adalah sebuah kerajaan pada pe rmulaan abad ke 15 . Banyak peninggalan-peninggalan terdapat di goa-goa di daerah ini yang diperkirakan dibuat pada abad ke 15 dan 16 seperti lukisan manusia terbang, prajurit bertombak dan lain-lain.

Pada zaman dahulu, daerah ini bernama wuna yang berarti bunga. Konon nama Wuna Ada karena adanya batu yang menyerupai bunga dan sewaktu-waktu tumbuh (orang menyebutnya kontu kowuna artinya batu berbunga). Suku-suku lain di Sulawesi Tenggara mengenal Muna juga dengan sebutan Wuna.Kecuali berbahasa Indonesia, tetap disebut dengan kata Muna.Kabupaten ini terletak diantara $4^{\circ} 6^{\prime}$ $5^{\circ} 15^{\prime}$ Lintang Selatan dan $120^{\circ} 123^{\circ} 24^{\prime}$ Bujur Timur.

Wilayah Kabupaten Muna sebelah 
Utara berbatasan dengan Kabupaten Konawe Selatan dan Selat Tiworo, di sebelah Selatan berbatasan dengan Kabupaten Buton, sebelah Timur berbatasan dengan Kabupaten Buton Utara, dan sebelah Barat berbatasan dengan Selat Tiworo.

Penelitian ini dilakukan di Desa Lakarinta, Kecamatan Lohia, Kabupaten Muna.Kecamatan Lohia berada di sebelah Selatan wilayah Kabupaten Muna yang berada di Propinsi Sulawesi Tenggara.Ibukota Kecamatan Lohia terletak di Desa Lohia. Kecamatan Lohia terdiri dari Sembilan (9) desa antara : Desa Lakarinta, Desa Bolo, Desa Korihi, Desa Liangkabori, Desa Mantobua, Desa Kondongia, Desa Wabintingi dan Desa Waara. Kecamatan loghia memiliki luas wilayah $48,91 \mathrm{~km}^{2}$.

\section{a. Kondisi Umum Desa Lakarinta}

\section{Sejarah Desa}

Desa Lakarinta merupakan 9 desa yang ada di Kecamatan Lohia Kabupaten Muna. Sebelum desa Lakarinta merupakan salah satu dusun dari Desa Mantobua. Seiring dengan waktu dan bertambahnya jumlah penduduk maka tokoh-tokoh masyarakat dan toko agama berkumpul dan bermusyawarah sehingga tercapai mufakat untuk melakukan pemekaran Desa Induk dalam hal ini Desa Korihi Dusun Loka. Desa Lakarinta pada saat itu kepala dusunnya La Inggirisi sedangkan kepala desa pada saat itu La Ifu. Bertolak dari pafa hal itu semua pada tahun 1984 maka maka terbentuklah Desa pemekaran dengan nama Desa Lakarinta. Nama Desa Lakarinta memilikin nama arti tersendiri yakni bermula dari sumber mata air Lakarinta yang bertempat dalam gua mata air tersebut .

\section{Keadaan Fisik/Geografi Desa}

\section{1) Batas Wilayah}

Secara geografis Desa Lakarinta terletak di sebelah Selatan Ibukota
Kecamatan Lohia dengan batas wilayah sebagai berikut :

- Sebelah utara berbatasan dengan Desa Lohia

- Sebelah selatan berbatasan dengan Kecamatan Tongkuno

- Sebelah barat berbatasan dengan Desa Korihi

- Sebelah timur berbatasan dengan Selat Buton

2) Luas Wilayah

Luas wilayah Desa Lakarinta adalah : 10,56 km2, terdiri dari

- Tanah perkebunan $\quad: 150 \mathrm{Ha}$

- Tanah pertanian $\quad: 468 \mathrm{Ha}$

- Tanah pekarangan : $15 \mathrm{Ha}$

- Tanah pemukiman : $60 \mathrm{Ha}$

- Tanah peternakan : $50 \mathrm{Ha}$

3) Keadaan Topografi Desa :

Secara umum keadaan topografi desa Lakarinta adalah merupakan daerah perbukitan/dataran tinggi dan sebagian dataran rendah dan daerah pesisir pantai.

\section{Keadaan Iklim}

Desa Lakarinta memiliki iklim seperti iklim desa lainnya di wilayah Indonesia yaitu memiliki iklim kemarau dan iklim penghujan.Iklim penghujan biasanya mulai pada bulan November sampai dengan bulan April tahun berikutnya, sedangkan iklim kemarau dimulai dari bulan Mei sampai dengan bulan Oktober.Iklim tersebut secara langsung mempengaruhi pola tanaman serta mata pencaharian masyarakat.

\section{b. Kondisi Pemerintahan Desa}

Desa lakarinta terbagi atas 2 dusun dengan potensi perangkatnya terdiri dari seorang Kepala desa, satu orang Sekretaris desa, dua orang kepala urusan, dua orang kepala seksi dan dua 
orang kepala dusun yaitu dusun 1 (Dusun Loka) dan 2 (Dusun Meleura) Adapun struktur organisasi pemerintahan Desa yaitu :

- Kepala Desa: La Riami

- Sekretaris Desa:Ld.Kamarudin,SKM

- Kaur Keuangan: Rusmiati

- Kaur Umum: La Ntobanga

- Kasi Pemerintahan: La Jamuli

- Kasi Eko. Pembangunan: Akbar

- Kadus I: La Ode Piliha

- Kadus II: Mohamat Sabrin

\section{B. Sejarah Pantai Meleura}

Meleura sendiri berasal dari kata Mele danUra (dalam bahasa kambowa), Mele dalam bahasa Indonesia artinya Pertemuan sedangkan Ura artinya Arus. Jadi meleura adalah pertemuan dua arus yaitu arus laut dan arus darat.Arus laut artinya berair asin sedangkan arus darat berair tawar.Pada zaman dahulu masyarakat sekitar sering mengambil air untuk keperluan seharihari seperti digunakan untuk minum, memasak, mencuci dan lain sebagainya.

Beberapa kilo meter dari meleura, ada sebuah situs purba yang terletak di ketinggian bukit kapur.Untuk menuju tempat ini dibutuhkan usaha dan fisik yang kuat. Jalan setapak sepanjang lima kilo meter (5 $\mathrm{km})$, tebing-tebing curam dan pucuk-pucuk karang yang tajam, menjadi tantangan yang sunggu menggelitik untuk dicoba. Di atas pada ketinggian dua ratus delapan puluh enam meter (286 meter) di atas permukaan laut, Gua Layang-layang tersembunyi dalam celah yang sepi. Gua yang menyerupai ceruk ini masih menyimpan lukisan karya manusia purba ribuan tahun lalu. Beberapa meter di atas Gua Layang-layang ada satu buah batu peta. Peta ini ditemukan beberapa tahun lalu oleh penjaga situs Gua liang kabori. Di meleura juga terdapat Gua-gua karang, tempat mandi, berenang dan atraksi budaya. Gua-gua yang terdapat pada area wisata Meleura menyebar mulai dari bibir pantai sampai kedarat hingga sejauh $1 \mathrm{~km}$. Yang mana Gua-gua ini terdiri dari Titolo, Ghonula, Amororondo, Sampuha dan Batu Malaria.

\section{HASIL PENELITIAN}

\section{Faktor Kekuatan Pengembangan Objek Wisata Pantai Meleura}

\author{
Adapun yang menjadi faktor \\ kekuatan atau pendorong dalam \\ pengembangan objek wisata pantai meleura \\ adalah:
}

a) Pemandangan alam yang indah, sejuk, asri, dan nyaman.

Potensi alam yang dimilikikawasanPantai meleura sangat mendukung keberadaan objek wisata ini. Pemandangan yang ditawarkan oleh wisata bahari ini yaitu berupa air laut yang jernih berwarna biru. Laut yang dangkal membuat pemandangan dasar laut dapat terlihat dari atas permukaan laut. Kedalaman laut pantai meleura berbedabeda tergantung sejauh mana wisatawan berenang. Untuk sekitaran bibir pantai sekitar setengah meter- 2 meter kedasar laut yang mana tergantung pasang surut air laut.Jarak antara bibir pantai dengan gazebo atau peristrahatan sejauh 3 meter.Saat sampai dikawasan wisata pantai meleura ini, wisatawan akan disuguhi pemandangan lautan berwarna biru jernih yang menyejukan mata. saking bening dan bersihnya air tersebut, anda bahkan dapat melihat isi dan dasar lautan dengan mata telanjang, mulai dari kumpulan ikan hingga pasir putih yang ada disana.

Di pantai meleura ini kita dapat menikmati indahnya alam dan udara sejuk yang jauh dari polusi, sehingga akan membuat setiap orang yang berkunjung akan merasa nyaman dan damai. Di sekitar pantai ini terdapat beberapa tebing dan pulau-pulau kecil mempunyai yang sangat indah punya potensi alam yang sangat indah yang sekarang kita manfaatkan menjadi daya tarik pariwisata buat meningkatkan ekonomi masyarakat yang ada disini.

\section{b) Fenomena alam yang unik.}

Dengan jarak 100 meter sebelum mencapai lokasi pantai meleura, wisatawan dapat menjumpai fenomena alam yang unik 
berupa gua terapung yang aksesnya berada dipinggir jalan yang bisa ditempuh dengan jalan kaki sejauh 5 meter dengan menjelajahi tebing-tebing kapur yang ada di bibir pantai.Bagi wisatawan yang hobi tantangan, objek wisata meleura adalah salah satu objek yang banyak menawarkan tantangan.Fenomena alam tersebut dapat dijumpai pada pantai meleura yang mana memiliki keindahan menajubkan dengan di dukung beberapa pulau yang berlubang dan gua-gua yang sangat besar serta desa nelayan yang mengambang. Jika memasuki gua tersebut maka akan terlihat beberapa lukisan kuda terbang. Didalam gua terapung pantai meleura juga dapat ditemukan formasi batu kapur yang tidak kalah menakjubkan.

\section{c) Masyarakat lokal yang ramah terhadap wisatawan.}

Masyarakat Desa Lakarinta
memiliki sikap yang ramah dengan
wisatawan. Salah satu karakteristik
masyarakat lokal ialah memiliki sikap
yang ramah karena masyarakat lokal yang
menerima dan melayani wisatawan yang
datang berkunjung sehingga dapat
membuat wisatawan nyaman datang untuk
berwisata.Berdasarkan pernyataan oleh
informan bahwa masyarakat Desa
Lakarinta sudah bisa menerima kehadiran
wisatawan dengan baik dan ramah karena
dengan meningkatnya wisatawan yang
berkunjung maka dapat meningkatkan
perekonomian mereka.

\section{d) Jarak tempuh objek wisata yang dekat dengan kota.}

Lokasi pantai meleura sangat mudah dijangkau dari kota Raha, dengan jarak dari kota Raha sampai dengan lokasi bisa ditempuh dengan jarak sekitar $18 \mathrm{~km}$ dan dapat ditempuh dalam waktu sekitar 30 menit dari pusat kota itu. Dengan banyaknya alat transportasi angkutan kota yang tersedia sampai sore hari, dengan satu kali naik angkutan umum( Jurusan Raha-Loghia) dan juga bagi yang membawa kendaraan pribadi akan mudah karena tidak banyak persimpangan yang harus dilalui .

\section{Faktor Kelemahan Pengembangan Objek Wisata Pantai Meleura}

Adapun yang menjadi kelemahan dalam pengembangan objek wisatayang menyebabkan kurangnya daya tarik wisata yang ada di pantai meleura yaitu :

\section{a) Kurangnya Sarana dan Prasarana.}

Untuk mewujudkan tata kelola yang baik terhadap pengembangan objek wisata diperlukan keseriusan, keterbukaan, dan kerja sama yang baik antar stakeholder dalam menjalankan tugas dan fungsinya. Yang tak kalah penting yang harus diperhatikan dalam pengembangan objek wisata adalah sarana dan prasarana pariwisata. Salah satu hal yang dapat menarik wisatawan untuk berkunjung kedaerah tujuan wisata adalah tersedianya sarana dan prasarana yang aman, nyaman, dan lengkap.

Pengadaan sarana dan prasarana wisata pantai meleura masih kurang. Dalam pelaksanaannya belum optimal yang dilakukan seluruh stakholder ( Pemerintah Daerah, Dinas pariwisata Kabupaten Muna) dalam pengadaan sarana dan parasarana di obyek tujuan daerah wisata.Berdasarkan hasil wawancara dengan informan bahwa kurangnya pengadaan sarana dan prasarana penunjang wisata pantai meleura. Sarana dan prasarana pengunjang wisata yang kurang diantaranya adalah tidak adanya homestay untuk pengunjung, lahan parkir yang kurang dan belum ada hak paten untuk tempat parkir.

\section{b) Keterbatasan anggaran (Dana)}

Dalam pengembangan objek wisata salah satu faktor penting yang menentukan maju atau tidaknya pengembangan adalah masalah dana. Jika dana tersedia maka pengembangan dapat berjalan dengan lancar tetapi jika dana tidak tersedia maupun kurang makan pengembangan objek wisata akan terhambat. Objek wisata 
pantai pun mengalami persoalan tersebut, hal ini dikarenakan dana pengembangan dan pembangunan objek wisata pantai meleura masih mengandalkan dana ADD ( Anggaran Dana Desa).

Keterbatasan ADD membuat pembangunan dan pengembangan objek wisata pantai meleura tersebut. Di samping itu belum adanya sponsor swasta yang mau membantu pngembangan juga mempengaruhi keterlambatan pengembangan untuk biaya sarana dan prasarana objek wisata pantai meleura. Berdasarkan hasil wawancara dengan Kepala desa pengembangan yang akan dilakukan untuk pariwisata pantai meleura masih dalam tahap perencaanaan dan akan direalisasikan pada tahun 2018-2019 memakai dana ADD. Karena dana yang masih terbatas jadi belum maksimal dalam pengadaan sarana dan parasarana untuk daerah objek wisata ataupun desa wisata dikarenakan anggaran dana yang terbatas.

\section{c) Keterbatasan Atraksi pada Objek Wisata}

Keterbatasan atraksi pada objek wisata pantai meleura menjadikan objek wisata ini belum mampu menahan pengunjung untuk berlama-lama dilokasi objek wisata. Di lokasi objek wisata pengunjung datang dan pergi setelah berfoto-foto dan berenang.Pengembangan pariwisata di suatu desa pada hakekatnya tidak merubah apa yang sudah ada di desa tersebut, tetapi lebih kepada upaya merubah apa yang ada di desa dan kemudian mengemasnya sedemikian rupa sehingga menarik untuk dijadikan atraksi wisata.

\section{Faktor Peluang Pengembangan Objek Wisata Pantai Meleura}

Adapun yang menjadi peluang dalam pengembangan objek wisata pantai meleura yaitu :

\section{a) Tempat Pariwisata yang berskala Nasional}

Melalui penataan dan pengembangan pariwisata di dalam upaya meningkatkan sekaligus menciptakan rasa aman bagi para wisatawan baik domestik maupun mancanegara berkunjung ke objek - objek wisata, alam, pantai dan wisata budaya di Kabupaten Muna khususnya di Desa Lakarinta secara terus menerus melaksanakan pengembangan dan menggalian potensi wisata dengan pengembangan destinasi objek wisata merupakan langkah-langkah yang ditempuh, agar dapat memberikan kontribusi bagi pendapatan daerah sehingga kelangsungan pembangunan dibidang kepariwisataan terus berjalan sesuai dengan tuntutan pembangunan daerah dalam upaya meningkatkan kesejahteraan masyarakat.

Pantai meleura merupakan objek wisata berskala Nasional, dan mampu bersaing dengan objek wisata di Indonesia dengan menampilkan keindahahan dan potensi alamnya yang baik. Keunggulan dari pantai meleura adalah Mengeksplorasi pesona keindahan alam dalam negeri dan kearifan lokal kini mulai menjadi trend di industri perfilman nasional. Begitu juga dengan film 'Jembatan Pensil', yang mengeksplorasi pesona keindahan Pantai Meleura destinasi wisata andalan Kabupaten Muna, Sulawesi Tenggara, dan destinasidestinasi wisata lainnya yang sangat indah dan kaya akan kearifan lokal. Sebuah film yang berkisah tentang petualangan dan persahabatan anak anak.Dipilihnya Kabupaten Muna sebagai lokasi shooting film 'Jembatan Pensil', karena Kabupatan Muna memiliki objek wisata yang sangat indah dan kaya akan kearifan lokal, Muna kaya objek wisata yang indah dan tidak dimiliki di daerah lain seperti pantai Meleura.

\section{b) Adanya Otonomi Daerah untuk mengembangkan Potensi Wisata}

Adanya Otonomi daerah memberi keleluasaan untuk mengembangkan potensi wisata, kebijakan otonomi daerah memberikan kewenangan kepada daerah 
untuk menggali potensi sumber daya alam yang ada dengan pemanfaatan kemajuan teknologi informasi serta letak geografis.

\section{c) Terbukanya lapangan pekerjaan bagi Masyarakat sekitar}

Itu menandakan bahwa peluang untuk pengembangan pantai meleura ini di masa yang akan datang sangat besar. Potensi wisata yang berlimpah di pantai meleura menjadi peluang yang sangat besar untuk menggali potensi wisata yang nantinya akan mnjadi daya tarik untuk dikembangkan untuk meningkatkan kunjungan para wisatawan. Desa Lakarinta lagi berkembang di bidang pariwisatanya, sebelum adanya wisata pariwisata ini, desa lakarinta masuk urutan kedua termiskin se kabupaten muna.Tetapi setelah adanya wisata, desa lakarinta menjadi desa yang berkembang. Dengan adanya wisata pantai ini dan semakin banyak pengunjung maka penjual/pedagang kaki lima disekiar pantai mendapatkan omset atau penghasilan lebih dari sebelumnya.

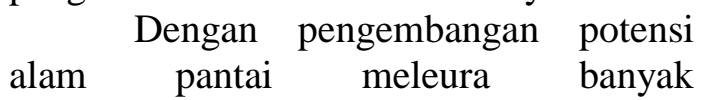
mendatangkan manfaat bagi masyarakat, seperti bertambahnya pendapatan masyarakat. Disamping nelayan dan bertani masyarakat sekitar desa lakarinta membuka usaha kecil-kecilan seperti warung kecil, usaha jasa ( penunjuk arah dan jasa perahu). Sehingga dengan adanya pantai meleura dapat mendongkrak ekonomimasyarakat.

\section{d) Banyaknya wisatawan yang ingin berkunjung}

Berdasarkan hasil penelitian yang saya lakukan dengan melakukan wawancara, informan mengatakan bahwa jumlah kunjungan wisatawan Pantai Meleura yang ada di Kecamatan Loghia Kabupaten Muna selama 4 tahun terakhir sejak tahun 2014 - 2018 bulan April memiliki peningkatan yang sangat signifikan, apalagi setelah diadakan festival meleura dengan konsep "Mai Te
Wuna yang digagas oleh Bupati Muna, Rusman Emba tahun 2017 kemarin dalam rangka mempromosikan pantai meleura orang berlomba-lomba untuk mengujungi wisata pantai meleura tersebut.

Menurut Kepala Dinas Pariwisata Kab. Muna bahwa : "Wisatawan asing sudah banyak yang bekunjung di pantai meleura ya sekitaran 20 0rang, mulai dari Amerika, Jerman, Australia dan negara lain begitupun dari wisatawan lokal dari Jawa, Kalimantan dan Sulawesi. Dan rencananya orang-orang dari luar atau wisatawan asing akan datang kembali berkunjung di pantai meleura ini”.

Promosi yang dilakukan Pemda Muna ini, membuat pantai meleura menjadi salah satu pilihan rute Sail Indonesia tahun 2018.

\section{Faktor Ancaman Pengembangan Objek Wisata Pantai Meleura}

Adapun yang menjadi ancaman dalam pengembangan objek wisata pantai meleura yaitu :

\section{a) Berkembangnya Objek Wisata Lain yang meningkatkan Persaingan}

Banyaknya objek wisata yang ada di Kabupaten Muna seperti pantai napabhale, pantai walengkabola, dan pantai wakumoro yang memberikan variasi bagi pengunjung dan memacu pengembangan objek wisata tersebut agar dapat menarik pengunjung dan memacu pengembangan objek wisata tersebut agar dapat menarik pengunjung. Untuk dapat bersaing dengan objek wisata lain perlu inovasi-inovasi untuk menarik pengunjung.

\section{b) Kerusakan Lingkungan akibat Pengembangan yang seenaknya}

Kerusakan lingkungan akibat pembangunan yang tidak tepat, merupakan ancaman yang disebabkan oleh manusia dan alam. Kesadaran pengunjung untuk ikut menjaga objek wisata merupakan hal penting agar pengunjung satu sama lainnya 
memperoleh kenyamanan dan menjaga keasrian objek wisata. Dalam pengembangan pun perlu berhati-hati agar tidak merusak lingkungan. Seperti yang disampaikan oleh informan bahwa :Pada saat melakukan pengembangan entah itu mau mendirikan sarana-sarana atau fasilitas-fasilitas ditempat ini harus memperhatikan kearifan lingkungan agar tetap terjaga kualitas lingkungan itu, apalagi dipantai meleura ini banyak karang-karang, beberapa jenis ikan jangan sampai itu bisa menghikangkan daya tarik tersebut".

Selanjutnya setelah mengetahui faktor kekuatan, kelemahan, peluang dan ancaman dalam mengembangkan objek wisata pantai meleura dapat dilakukan analisis SWOT. Dari analisis SWOT menghasilkan empat (4) kemungkinan strategi alternative, yaitu :

1. Strategi SO (Strength and Oppportunities), yaitu strategi yang mengoptimalkan kekuatan (strength) untuk memanfaatkan peluang (opportunities), ialah :

a. Mengelola potensi objek wisata yang dimiliki (pemandangan alam yang mendukung, fenomena alam yang unik dan suasana objek wisata yang memberikan kenyamanan) dengan otonomi daerah yang memberikan kewenangan pemerintah daerah untuk mengelola potensi daerahnya masing-masing.

b. Mengembangkan atraksi wisata seperti tempat permandian, pembuatan taman wisata, dan aquarium dibawah laut, pembuatan air terjun.

2. Strategi WO (Weaknesses and Opportunities), yaitu strategi yang meminimalkan kelemahan (weaknesses) dengan memanfaatkan peluang (opportunities), ialah :

a. Dengan otonomi daerah diharapkan dapat memberikan keluasan pemerintah daerah untuk mempromosikan potensi yang dimiliki objek wisata pantai meleura.

b. Aksesibilitas yang mudah menuju objek wisata pantai meleura dapat dicapai dengan memperbaiki jalan yang rusak dan pelebaran jalan sehingga meningkatkan jumlah pengunjung.

3. Strategi ST (Strength and Threats), yaitu strategi yang menggunakan kekuatan (strength) untuk mengatasi ancaman (threaths), ialah :

a. Mengoptimalkan potensi alam dan keunikan objek wisata dengan mempertahankan dan pemeliharaan objek wisata secara berkesinambungan untuk menghadapi persaingan antar objek wisata.

b. Kondisi kebersihan dan keamanan objek wisata yang baik membantu objek wisata dari pengunjung yang kurang sadar dalam menjaga keindahan serta kebersihan pantai.

c. Sumber-sumber daya yang dikembangkan secara hati-hati dan diupayakan agar tidak merusak lingkungan.

4. Strategi WT (Weaknesses and Threats), yaitu strategi yang meminimalkan kelemahan (weaknesses) dan menghindari ancaman (threats) ialah:

a. Melakukan pengawasan dan pemeliharaan fasilitas-fasilitas yang telah ada dilokasi objek wisata dan memperbaiki program pengembangan lebih bagus untuk menarik pengunjung sehingga siap untuk menghadapi persaingan antar objek wisata.

b. Peningkatan kualitas tenaga kerja professional dalam pengelolaan objek wisata sehingga mengurangi kerusakan lingkungan akibat pengembangan yang seenaknya. 
Dari hasil analisis SWOT yang dilakukan Objek Wisata Pantai Meleura, adapun analisis strategi yang digunakan adalah SO (Strength and Opportunities), dengan pertimbangan bahwa objek wisata pantai meleura mempunyai potensi alam dan potensi budaya yang banyak dan besar untuk dikembangkan, akan tetapi belum termanfaatkan secara optimal. Untuk itu dalam mengembangkan objek wisata pantai meleura harus menciptakan strategi dengan menggunakan kekuatan (strength) untuk memanfaatkan peluang (opportunities). Oleh karenanya atas dasar analisis lingkungan internal dan lingkungan eksternal tersebut diatas, maka kebijakan pengembangan pariwisata pantai meleura adalah :

1) Meningkatkan promosi mengenai objek wisata pantai meleura melalui berbagai media baik media cetak maupun media elektronik, pameranpameran wisata yang dilakukan oleh Dinas Pariwisata kabupaten muna

2) Meningkatkan sarana dan prasarana serta infrastruktur yang menujang seperti pembuatan taman wisata, perluasan tempat parkir, pembuatan jalan setapak, Penyediaan kuliner khas muna, pembuatan air terjun, penyediaan wahana permainan air seperti banana boat, akuarium dibawah laut, dan fasilitas-fasilitas penunjang lainnya sehingga dapat memberi kenyamanan dan menarik wisatawan untuk berwisata. Di samping itu perbaikan jalan yang rusak dan pelebaran jalan menuju objek wisata pantai meleura dapat memudahkan akses bagi pengunjung.

3) Pengembangan objek wisata pantai meleura memang perlu ditingkatkan apalagi semakin bertambahnya objek-objek wisata lain dan bertambahnya persaingan antar objek wisata maka objek wisata pantai meleura memerlukan inovasi baru untuk berkembang yang lebih baik. Pemerintah desa dan pemerintah daerah dalam mengembangkan objek wisata pantai meleura terkendala oleh dana maka perlu bantuan dari investor swasta

4) Dalam mengembangkan objek wisata pantai meleura perlu segera dilaksanakan pengembangan dan pembangunan terhadap potensi yang terdapat di objek wisata pantai meleura secara bertahap sesuai prioritas dengan memperhatikan nilai keunggulan saing dan keunggulan banding, kekhasan objek, kebijaksanaan pengembangan serta ketersediaan dana dan tenaga.

\section{PEMBAHASAN}

\begin{tabular}{ccr}
\multicolumn{2}{c}{ Penelitian ini membahas } & tentang \\
Strategi & Pemerintah & Desa dalam
\end{tabular} mengembangkan Objek Wisata Pantai Meleura di Desa Lakarinta Kecamatan Lohia Kabupaten Muna.Dari hasil penelitian berdasarkan wawancara dan observasi maka diperoleh informasi tentang kekuatan, kelemahan, peluang dan ancaman yang dimiliki oleh objek wisata pantai meleura.

Faktor Kekuatan yang ada pada objek wisata pantai meleura adalah Panorama alam yang indah, sejuk, asri dan nyaman, fenomena alam yang unik, masyarakat lokal yang ramah terhadap wisatawan, dan jarak tempuh yang dekat dengan kota. Objek wisata pantai meleura termasuk salah satu objek wisata yang bersih, aman karena tidak ada kasus pencurian, tindak kekerasan, dan perkelahian.

Selain kekuatan, objek wisata juga memiliki kelemahan yang harus diperhatikan.Kelemahan ini merupakan alat evaluasi dalam pengembangan objek wisata. Yang menjadi kelemahan dari objek wisata ini adalah kurangnya fasilitas sarana dan prasarana, keterbatasan anggaran atau dana untuk biaya pengembangan dan pembangunan. Tidak tersedianya sarana seperti restoran/rumah makan, yang ada hanya warung sederhana yang menyediakan mie instan dan makanan-makanan ringan lainnya. Keterbatasan sarana seperti hotel/penginapan membuat pengunjung tidak bisa menghabiskan waktunya lebih dari 24 jam dilokasi objek wisata ini dan 
keterbatasan atraksi pada objek wisata ini belum mampu menahan pengunjung untuk berlama-lama dilokasi objek wisata.

Selanjutnya peluang adalah kemampuan yang dimiliki oleh suatu daerah untuk dapat dimanfaatkan dan berkembang dimasa yang akan datang. Peluang ini bertujuan untuk memajukan objek wisata.Adapun peluang yang dimiliki oleh objek wisata pantai meleura adalah tempat pariwisata yang berskala nasional, adanya otonomi daerah yang memberi keleluasaan untuk mengembangkan pariwisata, terbukanya lapangan pekerjaan bagi masyrakat sekitar dan banyaknya wisatawan yang ingin berkunjung.

Dari peluang maka akan muncul ancaman. Ancaman berasal dari luar yang dapat mengancam pengembangan objek wisata pantai melaura. Adapun ancaman terhadap objek wisata pantai meleura adalah berkembangnya objek wisata lain yang ada di kabupaten muna dan berada juga dikecamatan lohia seperti pantai napabhale. Untuk dapat bersaing dengan objek wisata lain, objek wisata pantai meleura perlu inovasi untuk menarik pengunjung. Kerusakan lingkungan akibat pengembangan yang tidak tepat dan seenaknya merupakan ancaman yang disebabkan oleh manusia dan alam.

Selanjutnya sesuai dengan kekuatan, kelemahan, peluang dan ancaman, maka strategi yang dapat dilakukan dalam mengembangkan objek wisata pantai meleura sesuai dengan analisis SWOT adalah menghasilkan empat alternative strategi yaitu alternative strategi SO (ciptakan strategi yang menggunakan kekuatan untuk memanfaatkan peluang), Strategi WO (strategi yang meminimalkan kelemahan untuk memanfaatkan peluang), strategi ST (strategi yang menggunakan kekuatan untuk mengatasi ancaman) dan strategi WT (strategi yang meminimalkan kelemahan-kelemahan dan menghindari ancaman).

Perumusan strategi pengembangan Objek Wisata Pantai Meleura menggunakan analisis SWOT. Analisis SWOT adalah analisis yang mengkombinasikan antara kekuatan, kelemahan, peluang, dan ancaman. Berdasarkan kekuatan, kelemahan, kekuatan dan ancaman yang dimiliki oleh Objek Wisata Pantai Meleura maka diperoleh strategi yang bisa dilakukan oleh pemerintah desa yaitu :

1. Meningkatkan promosi objek wisata Pemasaran atau promosi dan inovasi kegiatan-kegiatan pariwisata penting untuk dilakukan karena hal tersebut dapat menarik minat wisatawan untuk berkunjung. Dalam promosi dan inovasi pariwisata harus didukung dengan ketersediaan sarana dan prasarana yang menarik dalam obyek wisata, sehingga mampu mempengaruhi pengunjung untuk datang.

2. Meningkatkan sarana dan prasarana serta infrastruktur yang menunjang seperti pembuatan taman wisata, pembuatan air terjun, perluasan parkir, penyediaan wahana permainan air seperti banana boat, aquarium dibawah laut, dan fasilitas-fasilitas penunjang lainnya sehingga menarik dan memberi kenyamanan bagi pengunjung. Disamping itu perbaikan jalan yang rusak dan pelebaran jalan tentunya dapat memudahkan akses bagi pengunjung Objek Wisata Pantai Meleura.

3. Memanfaatkan potensi yang ada yang dimiliki Objek Wisata Pantai Meleura yaitu potensi alam dan potensi budaya. Mengingat bertambahnya objek wisata lain dan bertambahnya persainganpersaingan antar objek wisata maka Objek Wisata Pantai Meleura memerlukan inovasi baru untuk berkembang yang lebih baik dan menjalin kerjasama dengan pihak swasta.

4. Mengadakan akomodasi pariwisata baik itu hotel, maupun villa, mengembangkan atraksi wisata dan melakukan koordinasi dengan pihak swasta untuk menanamkan modal.

\section{PENUTUP}

\section{A. Kesimpulan}

Berdasarkan uraian pada hasil penelitian dan pembahasan, maka dapat 
disimpulkan bahwa perumusan strategi pengembangan Pantai Meleura di Desa Lakarinta Kecamatan Lohia Kabupaten Muna dengan menggunakan analisis SWOT. Analisis SWOT adalah analisis yang mengkombinasikan antara kekuatan, kelemahan, peluang, dan ancaman.

1. Faktor kekuatan yang ada pada objek wisata pantai meleura adalah panorama alam yang indah, sejuk, asri, dan nyaman, fenomena alam yang unik, masyarakat sekitar ramah terhadapwisatawan, dan jarak tempuh yang dekat dengan kota. Selain kekuatan, objek wisata juga memiliki kelemahan yang harus diperhatikan. Yang menjadi kelemahannya adalah kurangnya fasilitas sarana dan prasarana, keterbatasan anggaran untuk biaya pengembangan, dan keterbatasan atraksi pada objek wisata. Selanjutnya peluang yang dimiliki oleh objek wisata ini adalah tempat pariwisata berskala nasional, adanya otonomi daerah, terbukanya lapangan pekerjaan bagi masyarakat sekitar dan banyaknya wisatawan yang ingin berkunjung. Dari peluang maka akan muncul ancaman, adapun ancaman terhadap objek wisata pantai meleura adalah berkembangnya objek wisata lain, dan kerusakan lingkungan akibat pengembangan yang seenaknya.

2. Berdasarkan kekuatan, kelemahan, peluang dan ancaman dalam pengembangan objek wisata maka diperoleh strategi yang bisa dilakukan oleh pemerintah desa yaitu :

1. Meningkatkan promosi objek wisata. Pemasaran atau promosi dan inovasi kegiatan-kegiatan pariwisata penting untuk dilakukan seperti promosi di media sosial, brosur-brosur yang disebar kepada orang-orang, karena hal tersebut dapat menarik minat wisatawan untuk berkunjung.

2. Meningkatkan sarana dan prasarana serta infrastruktur yang menunjang seperti pembuatan taman wisata, pembuatan atau pembangunan air terjun, penyediaan kuliner khas muna, perluasan parkir, penataan parkir, penyediaan wahana permainan air seperti banana boat, aquarium dibawah laut, dan fasilitas-fasilitas penunjang lainnya sehingga menarik dan memberi kenyamanan bagi pengunjung. Disamping itu perbaikan jalan yang rusak dan pelebaran/perluasan jalan tentunya agar dapat memudahkan akses bagi pengunjung Objek Wisata Pantai Meleura serta melakukan kerja sama atau koordinasi dengan pihak swasta untuk menanamkan modal.

Beberapa saran yang dapat diajukan berdasarkan hasil penelitian ini adalah :

1. Untuk menunjang pengembangan objek wisata, aksesibilitas menuju ke lokasi objek wisata dan daya tarik wisata yang terdapat di objek wisata pantai meleura perlu ditingkatkan.

2. Dinas pariwisata, pemerintah daerah, pemerintah desa, pengelola serta masyarakat harus saling berkontribusi dan tetap berkerja sama agar pembangunan dan pengembangan pantai meleura cepat terlaksanakan. karena melihat hambatan dalam pengembangan pantai meleura yang sangat utama karena terbatasnya dana/anggaran sehingga pemerintah daerah bisa mengusulkan ke pemerintah pusat dan bisa bekerja sama.

\section{DAFTAR PUSTAKA}

Craig \& Grant 1996.Manajemen Strategi. Jakarta: Alex Media Komputindo Kelompok Gramedia.

Fandeli, Chafid. 1995. Dasar-Dasar Manajemen Keparwisataan Alam.Penerbit Liberty.Yogyakarta.

Hadiwijoyo, Suryo Sakti. 2012.Perencanaan Pariwisata Perdesaan Berbasis Masyarakat. Yogyakarta: Graha Ilmu. 
Marpaung, Happy. 2000. Pengetahuan Kepariwisataan. Bandung:

Alfabeta.

Marpaung, Happy. 2002. Pengantar pariwisata. Bandung: Alfabeta.

Pitana, I. Gede dan Gayatri, Putu G. 2005.Sosiologi Pariwisata. Yogyakarta: Andi.

Salusu J, 1998. Pengambilan Keputusan Stratejik, Jakarta: Grasindo.

Surasih, Maria Eni. 2003. Pemerintah Desa dan Implementasinya. Jakarta: Erlangga 